\title{
Boric Acid And Hazard Analysis Critical Control Point (HACCP) On Kerupuk To Improve The Indonesian'S Traditional Foods Safety
}

\author{
Anita Dewi Moelyaningrum
}

\begin{abstract}
Diseases can be caused by consumption of contaminated food such as toxicant. Kerupuk are one of the traditional foods produced by some of the traditional industries in Jember. The objective of this study was to identify the content of borix acid and analyze hazards and determine the critical control points on tofu crackers. This could raise the traditional food safety for consumers. This study was a descriptive study conducted by interview and observation. Boric acid testing was carried out on five samples of kerupuk. Instrument sheets referred to the SNI CAC RCP1-2011. The results indicated that $100 \%$ of the samples contained boric acid. The selection of materials, slicing, drying and distribution were the control points while mixing and kneading, steaming, frying and packaging were the critical control point. Boric acid is still used on tofu kerupuk; therefore, the government should immediately provide information and training on sustainable traditional food industry to reduce the incidence of illness and food poisoning in traditional food.
\end{abstract}

Keywords: Boric acid, HACCP, tofu kerupuk

\section{INTRODUCTION}

The problems of food safety are still a concern of the international health organization. Food can cause illness or as a medium of transmission of diseases, such as through consumption of contaminated foods or foods containing hazardous materials. The World Health Organization (WHO) states that globally there are around 960 food problems or called foodborne illnesses and 600,000 deaths in 2010 [1]. This also occurs in Indonesia with the number of this country's food poisoning incidences in 2010 -2014 reaching 1,218 cases. Food poisoning can be from household, catering, or school snacks [2]. Foodborne diseases can be due to microbiological contaminations such as typhoid, cholera, dysentery, hepatitis $A$, etc. Food poisoning can also be caused by the use of hazardous substances such as borix acid, formaldehyde, rhodamine, methanil yellow, etc. Home-made foods are foods produced in the household scale, one of which is kerupuk. Tofu's kerupuk made from tapioca flour and wheat flour, and tofu is a type of traditional snacks produced by some household industries in Jember District. Food safety is absolutely necessary to ensure public health. Food safety is a condition and effort needed to prevent food from contamination possibilities, such as biology, chemistry, and other objects that could disturb, detriment, and harm to human health as well as do not conflict with religion, beliefs, and community cultures so that they are safe for consumption. Everyone has a responsibility to guarantee food safety. For that, in any food chain including production, storage, transportation and distribution, food should be eligible for sanitary requirements [3]. To meet the sanitary requirements throughout the food chain, there should be protocols carried out, such as hazard analysis and determination of critical control point or called Hazard Analysis Critical Control Point (HACCP). HACCP is a tool to assess the hazards and establish control systems focused on prevention rather than relying on end-product testing [4]. The HACCP system has been internationally recognized for realizing food safety and preventing foodborne illness. The purpose of this study was to conduct hazard analysis and critical control point in the process of making tofu's kerupuk, including an analysis of potential chemical hazards in the form of non-food additives such as boric acid in the final product. With the implementation of HACCP analysis, it was expected to improve the quality of Indonesian traditional food safety

\section{METHODS}

This was a descriptive study with quantitative and qualitative approaches. Data were collected by interview and observation referring to the instrument of HACCP assessment, i.e, [4] Data from interviews and observations were then analyzed using an analytical method of the severity and the risk of harm, the method of determining the significance of hazards and the use of decision tree diagram. Five samples were taken randomly from five manufacturers to see the content of boric acid.

\section{RESULTS AND DISCUSSION}

\section{Product Description}

The products were in the form of ready-to-eat kerupuk. The dry dough was ready to be fried in hot oil. Tofu's kerupuk could last up to 1 month in a air-proof plastic package. The complete description of kerupuk product is in Table 1.

Table 1. Product Description

\begin{tabular}{lll}
\hline No & Criteria & Description \\
\hline 1. & Product Name & Tofu crackers \\
\hline 2. & Trademark Name & Not available \\
\hline 3. & Composition & $\begin{array}{l}\text { Tapioca flour, wheat flour, tofu, various } \\
\text { spices, food additives }\end{array}$ \\
\hline 4. & Packaging & Clear plastic \\
\hline 5. & Consumers & All ages and all levels of society \\
\hline
\end{tabular}

\section{Production process}

Tofu crackers was made by mixing flour and mixed spice. Once the dough was cooked, dried and molded, the crackers were ready for frying. The complete process of the production is in the following chart (fig. 1): 


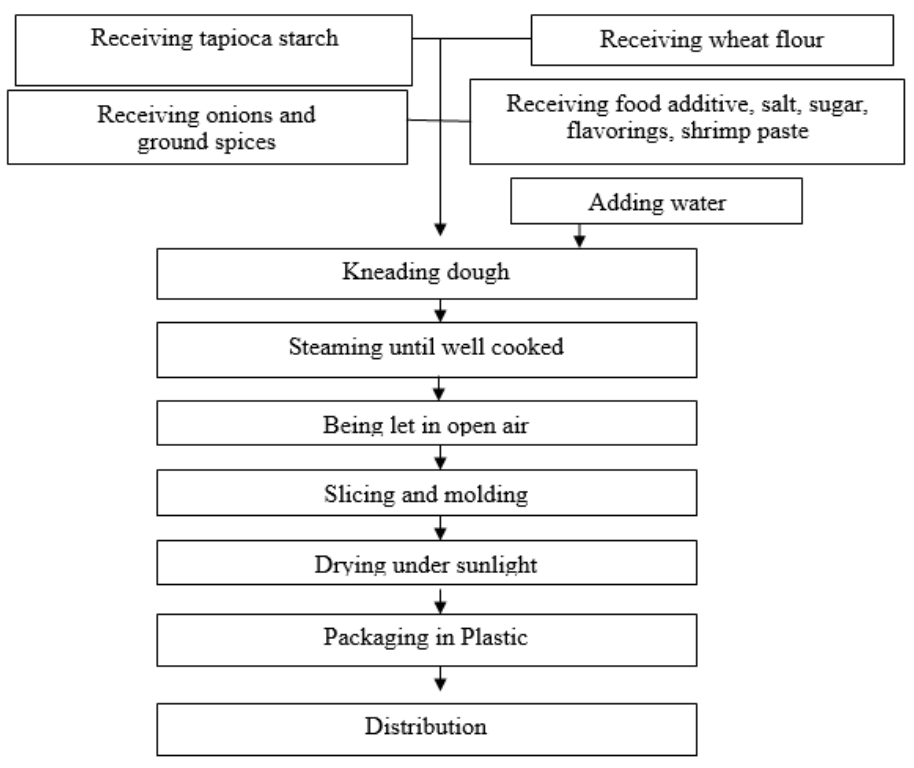

\section{Hazard analysis}

After making the flow diagram of the production process, hazard analysis was carried out on every production process with identification of all potential hazards expected to reduce the quality of food production. At every stage of the production process, it allowed the presence of potential physical, biological and chemical hazards. Potential physical hazards included physical dirt like the remains of the pack, hair, crosscontamination of containers, tools, workers and the surrounding environment. Potential biological hazards could be fleas on powdery material, bacteria from water used, containers, tools, contacts with the workers and the surrounding environment which was less hygiene. Potential chemical contaminants could originate from the unsafe use of food additives (BTP) or prohibited materials for food, as well as the repeated use of cooking oil. The analysis of all the potential dangers that might arise at each stage of the production process is in Table 2.

Figure 1. Flow chart of the process of Tofu Kerupuk production

Table 2. Analysis of potential hazards at every stage of the production process

\begin{tabular}{|c|c|c|c|c|}
\hline Stages of process & Hazard & Sources of hazard & Justification & Prevention \\
\hline $\begin{array}{l}\text { Material Selection: } \\
\text { Tapioca flour } \\
\text { Wheat flour }\end{array}$ & $\begin{array}{l}\text { Physical }(P) \\
\text { Biology }(B) \\
\text { Chemistry }(C) \\
\end{array}$ & $\begin{array}{l}\text { Flour dirty, contaminated } \\
\text { with chemicals and } \\
\text { moldy }\end{array}$ & Moderate risk & $\begin{array}{l}\text { Sorting } \\
\text { Pay attention to the } \\
\text { quality of flour }\end{array}$ \\
\hline $\begin{array}{l}\text { Kneading: } \\
\text { Water } \\
\text { Seasoning } \\
\text { Food additives }\end{array}$ & $\begin{array}{l}\text { Physical }(P) \\
\text { Biology }(B) \\
\text { Chemistry }(C)\end{array}$ & $\begin{array}{l}\text { - Cross-contamination } \\
\text { of workers, } \\
\text { containers and tools } \\
\text { - Mixing food additives }\end{array}$ & $\begin{array}{l}\text { Moderate risk } \\
\text { High risk }\end{array}$ & $\begin{array}{l}\text { Implementation of } \\
\text { worker hygiene, } \\
\text { good tools and } \\
\text { containers } \\
\text { The use of food } \\
\text { additives }\end{array}$ \\
\hline Steaming & $\begin{array}{l}\text { Physical (P) } \\
\text { Biology (B) } \\
\text { Chemistry (C) }\end{array}$ & $\begin{array}{l}\text { - Cross-contamination } \\
\text { of water steamer, } \\
\text { tools. } \\
\text { - Incompatible } \\
\text { temperature }\end{array}$ & $\begin{array}{l}\text { Moderate risk } \\
\text { High risk }\end{array}$ & $\begin{array}{l}\text { - Cassava Cutlery } \\
\text { Sterilization } \\
\text {-Washing of Cutlery }\end{array}$ \\
\hline Slicing & $\begin{array}{l}\text { Bacteria, } \\
\text { chemical }(B, C)\end{array}$ & $\begin{array}{l}\text { cross-contamination of } \\
\text { the container, tool, } \\
\text { worker }\end{array}$ & Moderate risk & $\begin{array}{l}\text { Use of container, } \\
\text { clean tools,. } \\
\text { Higiene of the } \\
\text { workers }\end{array}$ \\
\hline Drying & $\begin{array}{l}\text { Physical }(P) \\
\text { Biology }(B) \\
\text { Chemistry }(C)\end{array}$ & $\begin{array}{l}\text { Cross-contamination } \\
\text { from dust, tools and } \\
\text { surrounding environment } \\
\text { around the drying }\end{array}$ & $\mathrm{t}^{\text {Moderate risk }}$ & $\begin{array}{l}\text { The use of water } \\
\text { which meets the } \\
\text { physical, chemical, } \\
\text { biology requirements } \\
\text { for cassava cleaning }\end{array}$ \\
\hline Frying & Chemical & $\begin{array}{l}\text { - } \text { Oil for frying } \\
\text { - } \quad \text { Frying tool }\end{array}$ & High risk & $\begin{array}{l}\text { - Correct use of } \\
\text { cooking oil } \\
\text { - selection of food } \\
\text { grade tools and } \\
\text { materials }\end{array}$ \\
\hline Packaging in plastic & $\begin{array}{l}\text { Physical, } \\
\text { Biology (P, B) }\end{array}$ & $\begin{array}{l}\text { Cross contamination } \\
\text { from workers, container }\end{array}$ & High risk & $\begin{array}{l}\text {-Implementation of } \\
\text { worker, container } \\
\text { and tool hygiene }\end{array}$ \\
\hline Distribution & $\begin{array}{l}\text { Physical, } \\
\text { Biology (P, B) }\end{array}$ & $\begin{array}{l}\text { - Cross-contamination } \\
\text { of room, handlers }\end{array}$ & Moderate risk & $\begin{array}{l}\text { Implementation of } \\
\text { storage room, } \\
\text { worker, container, } \\
\text { and tool sanitation }\end{array}$ \\
\hline
\end{tabular}

Determination of critical control point

After the analyses of all potential hazards were carried out at every stage of the process, a decisions tree diagram was used to determine which stage was the critical point (CP) and which stage was the critical control point (CCP). At each stage of the process, monitoring, verification and evaluation and 
documentation should be performed. From the analysis of potential hazards at each production process, it was discovered that four stages were a critical control point (CCP). The four stages had to be controlled by the determination of the critical limit. Four stages controlled were the mixing and the formation of the dough, steaming, frying, and packaging. The stages not as the critical control points were critical point (CP), ie, material selection, slicing, drying, and distribution. Critical limits were determined at each critical control point (CCP) to control the quality of food. The specified parameters of critical limits included the limits of physical, biological, and chemical contamination. Critical limit of physical contamination at dough making was physical sorting such as the presence of any unwanted objects like hair and bits of packaging material and the water used. The critical limit of biological contamination needed to be determined by looking at the content of microorganisms such as eschercia coli, salmonella, fungus, etc., in the water used, and the existence of crosscontamination of cooking tools, container, and contact with the workers and the environment in the production. Critical limits of chemical contamination were determined to prevent potential chemical hazard to enter via food. Critical limits for parameters of chemical contaminants could be performed on the stage of dough making in which all the materials used were safe materials or food grade. At the stage of frying, process critical limits were determined in the use of cooking oil. Likewise, for the water used, it met requirements of water quality. Cooking tools and containers had to be tools that did not react with foods such as stainless steel. The complete critical control points could be seen in Table 3 .

Table 3. Analysis of Critical Control Point in each stage of the production process

\begin{tabular}{|c|c|c|c|c|c|}
\hline \multirow[t]{2}{*}{ Stage } & \multirow[t]{2}{*}{$\begin{array}{l}\text { Type of } \\
\text { Hazard }\end{array}$} & \multirow[t]{2}{*}{ Critical limits } & \multicolumn{2}{|l|}{ Monitoring } & \multirow[t]{2}{*}{ Correction } \\
\hline & & & method & frequency & \\
\hline Dough making & chemistry & $\begin{array}{l}\text { ingredients, } \\
\text { seasonings and } \\
\text { food additives are } \\
\text { materials that are } \\
\text { safe for } \\
\text { consumption }\end{array}$ & $\begin{array}{l}\text { conditions of material } \\
\text { and label food grade on } \\
\text { raw material packages }\end{array}$ & Each proce & $\begin{array}{l}\text { Terminate the process } \\
\text { when the visual } \\
\text { appearance and texture } \\
\text { is not good }\end{array}$ \\
\hline Steaming & Biology & 60 minutes & $\begin{array}{l}\text { Steaming until well- } \\
\text { cooked }\end{array}$ & Each process & $\begin{array}{l}\text { - Continue the process } \\
\text { s when the is still less } \\
\text { - Adjust the temperature }\end{array}$ \\
\hline Frying & Chemical & $\begin{array}{l}\text { Cooking oil is used } \\
\text { only } 2 x\end{array}$ & Recording of use & Each process & $\begin{array}{l}\text { shen the physical } \\
\text { condition of the oil looks } \\
\text { black }\end{array}$ \\
\hline Packaging & $\begin{array}{l}\text { Physical } \\
\text { Biological }\end{array}$ & $\begin{array}{l}\text { Negative of e.coli, } \\
\text { salmonela, densed } \\
\text { vectors, Room. }\end{array}$ & $\begin{array}{l}\text { The use of gloves, } \\
\text { measurement of room } \\
\text { temperature. }\end{array}$ & $\begin{array}{l}\text { Each process } \\
\text { - Every day } \\
\text { for storage }\end{array}$ & $\begin{array}{l}\text { s separation of defective } \\
\text { products, measurement } \\
\text { of room temperature }\end{array}$ \\
\hline
\end{tabular}

\section{Discussion}

The selection of materials, both raw materials and additives in making the product must meet the requirements. In the production of kerupuk, the good and right selection of raw materials such as tapioca flour and wheat flour will produce good food quality as well. The selection of tapioca starch and wheat flour should be qualified as food materials [5]. The flour quality is physically determined by the color, appearance, smell, and texture. Sorting could be done to get the flour free from physical contaminants. Flour quality is biologically determined based on the content of microbes while the chemical quality is free from chemical contaminants such as heavy metals. At the stage of making the dough, there is potential for the physical, biological and chemical contamination. Physical potential can occur from crosscontamination of cooking tools, containers, contact from the workers and the environment in the production. Cookware and containers should be washed and dried before used. The crust on the cooker that is less clean can reduce the quality of food physically. Food containers should be made of clean and safe material. Clean container will reduce the potential for contamination, both physically and bacteriologically. The safe containers for food will prevent the existence of reaction of hazardous materials when food is being cooked. Biological contaminants can originate from contact with workers. Healthy human beings can also be the source of microbial contamination of the skin, nose, mouth and throat. Therefore, the food handler can potentially become a source of contaminants in food. Mixing raw materials, spices, food additive and water into dough of tofu's kerupuk requires the contact of workers' hands. To avoid cross-contamination of workers, the workers should not use jewelry, gloves, hair cover, and apron and are not sick, not smoking and washing hands before touching or process the food (Decision of Health Minister of Republic of Indonesia 942/ 2003). The jewelry worn by a food handler can be a source of contaminants due to dirt on the jewelry that falls on food. Nevertheless, there are still many food handlers who wear jewelry when preparing food, do not wear aprons, and do not use the head cover [7]. There were sig correllation betwen hygiene food handler and the existing microbe in the water [8] and also sig correllation with the microbe in the grilled fish and equipment [9]. Water used in the production process can be a source of contaminants in food. Water is directly used in the stage of making dough and steaming the dough until cooked. For that, the water used must meet the requirements of clean water quality (Health Minister Regualation 416/1990). Containers and steamer tools must be clean and safe for processing food. At the stage of 
the cooling the dough, ie, being let in open air and dried, the potential contamination is from the dusty environment and the containers used as the base for drying. At the stage of slicing or molding, potential dangers come from food handlers, slicer and containers used. Handlers who do not use gloves and crust from the slicer are potential as a source of the entry of physical and microbial contamination. At the stage of the packaging process, the potential danger can be from crosscontamination of food handlers while at the stage of the process of distributing the room conditions are also potentially dangerous.

\section{Determination of Critical Control Point (CCP)}

Determination of critical control point (CCP) is an important stage to control the production process so that contaminants in food could be controlled and the quality of the food could be properly maintained. Critical limits determined to reduce the potential chemical hazards in the kneading are the selection and use of food grade-labeled raw materials and food additives. Monitoring is conducted at each stage of the process. Making a decision whether each stage is included at the stage of CCP or CP is done with decision-making tools i.e. decisions tree diagram. At the entry stage as CCP control, monitoring and correction on any potential dangers must be done so that food quality is maintained. Control is done with the determination of critical limits, monitoring and correction at any stage. At this stage of kneading, there are potential dangers that must be controlled. In the process of making dough or kneading, all the raw materials used, such as condiments, water and food additives used, must be properly allocated for food, so that it is safe for consumption. It also included the tools, containers used, as well as contact with food handlers because they can be a source of contaminants in food. However, the most potential as a source of danger is the chemical contamination from the selection of raw materials, seasonings and food additives as the dough mixture. Materials and spices selected as food must be good and safe for consumption. Water used in the production of foods should meet the quality requirements of clean water, good physical condition, chemistry, biology and radiation. (Health Minister Regualation 416/1990). Food additives are commonly used in the production process of food for reasons of taste, texture, appearance and aesthetics. The use of food additives in food processing must comply with applicable laws and regulations [11]. Use of food additives in traditional foods or food production of household industry needs attention. Often, it is found that some foods contain hazardous materials. Some results of study show that many foods still commonly contain food additives banned such as boric acid [12] [13] [14] [15]. The seven of tofu's kerupuk industries in this study, five samples were randomly taken. The analysis showed that all the samples were positive containing borax. Borix acid is sodium tetraborate salt ( $\mathrm{Na} 2 \mathrm{~B} 4 \mathrm{O} 7 \mathrm{10H} 2 \mathrm{O}$ ) in the form of a white crystalline powder with the odorless characteristic, soluble in water and insoluble in alcohol and with $\mathrm{PH}: 9.5$. Borax is an antimicrobial substance often used in non-food industries, such as paper industry, wood preservatives, ceramics, etc. Boric acid is a hazardous substance often used in the process of food production [16]. Boric acid is banned from the use in food [11]. The value of Borax Lethal Dose (LD50) is $2.660 \mathrm{mg} / \mathrm{kg}$ of body mass. Borax has harmful toxic effects. Borax acid was not allowed to enter the body because it could damage liver [17] and had the effect of carsinogenic
[18], testis death [19]. At the stage of steaming, the potential physical contaminants could originate from the water used. For that, the water used for cooking must meet the physical, biological and chemical requirements. Steaming is a cooking way by using steam from the water boiled. Heating is done to reduce microbiological contaminants including Escherichia coli. One of the parameters of food quality often used to look at the appropriateness of the food consumed is that the materials do not contain e.coli (Health Ministry Regulations No.1096 2011). The inspection of hospital food quality also sees the parameter of e. coli and Salmonella sp to determine the quality of food consumed by the patient [21]. The presence of $E$. coli indicates that the food is contaminated with feces that could transmit a variety of diseases transmitted by vekal oral. However in the market, foods that contain e.coli are still found [22]. Right heating is expected to produce foods that have good tastes and can kill pathogenic microbes so that the food is safe to eat. Critical limits are stipulated that steaming is done until the dough is well cooked for at least 60 minutes and unti the water boils. Correction at this stage is done by looking at the appearance of the dough. If it looks not well-cooked yet, steaming could be continued. At this stage of frying, the most potential danger is the chemical hazards of the repeated use of frying oil, for example, palm oil. In the frying process, critical limits determined are that the cooking oil is used no more than 2 times of cooking where the monitoring is done by periodically recording related to the use of cooking oil. Corrective actions are taken by terminating the process when the oil already looks black. Blackish color on cooking oil shows that the quality of the cooking oil is already bad. The repeated use of palm oil can increase the content of trans fatty acids that are harmful to health. Frying with palm oil should not be more than 2 times of use [23]. The increase of free fatty acids in the fried products is directly proportional to the number of repetitions [24]. The quality of oil used repeatedly for frying will be down [25]; therefore, palm oil should not be used repeatedly. At the packaging stage, personal protective equipment to workers to reduce directly contact with food should be used by workers, i.e., gloves, headgear and masks. The sanitation of packing place of cooked products also needs to be considered to control the physical and biological contaminants. For that, the temperature measurement of storage room of cooked products should be done. This includes testing of food samples both microbiological and chemical analyzes of the food cooked. The HACCP system is considered effective to ensure food quality. This is because the instrument of HACCP assessment is carried out on each chain of the production process, not just relied on a test sample of the final product. The application of HACCP in traditional food needs to be done so that traditional food can be assured its quality, and developed in both domestic market and overseas market. Supports from the government and producers are the main elements so that HACCP can be implemented in all countries worldwide [26] .

\section{CONCLUSION}

Tofu's kerupuk are a traditional food consumed by all age groups. From the hazard analysis it can be determined that the critical points are the selection of materials, slicing, drying and distribution while the critical control points are kneading, steaming, frying, and packaging. Potential chemical hazards include the use of food additives which are not allowed such as boric acid. The government should immediately provide 
information and training related to food sanitation and HACCP, as well as the selection of safe food additives in the traditional food industry. This needs to be done continuously and sustainably to reduce the incidence of illness and food poisoning due to traditional food. In addition, it is necessary to develop boric acid substitutes that are safe to be used and economically affordable

\section{References}

[1] WHO, "Who estimates of the global burden of foodborne diseases," 2015.

[2] Badan Pengawas Obat Makanan Indonesia, "Angka Keracunan Makanan Capai 1.218 Kasus," 2015.

[3] Goverment Regulation No. 28, Goverment Regulation no 28 about safety, quality and nutrition of food. 2004.

[4] Indonesian National Standart CAC/RCP 1-, Badan Standart Nasional Indonesia. 2011.

[5] Indonesian National Standart 3751, SNI No 01-3751. 2009 Mutu Tepung Terigu sebagai Bahan Makanan. 2009.

[6] N. 942 / Decision of Health Minister of Republic of Indonesia, Decision of Health Minister of Republic Indonesia, No. 942 about Guidane Requirements Food Higiene of snack. 2003, pp. 1-21.

[7] T. dan A. R. Agustin, "Higiene dan sanitasi nasi tempe penyet pedagang kaki lima jalan karangmenjangan surabaya," J. Kessehatan Lingkung., vol. 4, no. 2, pp. 69-80, 2008.

[8] M. N. Mirza, "Hygiene Sanitasi dan Jumlah Coliform Air Minum," J. Kesehat. Masyarakat, KEMAS, vol. 9, no. 2, pp. 167-173, 2014.

[9] D. Suryani, "Jurnal Kesehatan Masyarakat," J. Kesehat. Masyarakat, KEMAS, vol. 9, no. 09, pp. 191196, 2014.

[10] Health Minister Regualation 416/1990, "Minister of Health of Indonesia Number 416/ 1990." 1990.

[11] Regulation of the Minister of Health of the Indonesian No 33/, Regulation of the Minister of Health of the Indonesian No 33 about Food Additive. 2012.

[12] N. Fatimah, "Studi Kualitatif Penggunaan Boraks Pada Kerupuk Di Desa Merak Kecamatan Dempet Kabupaten Demak," 2006.

[13] P. Sultan et al., "Analysis Of The Content Of Borax On Mearballs Snack In SDN Kompleks Mangkura In Makasar City," Media Kesehat. Masy. Indones., pp. 111, 2014.

[14] L. K. Muharrami, "Analisis kualitatif kandungan boraks pada krupuk puli di kecamatan kamal," vol. 2, no. 2, 2015.
[15] Habsah, "Gambaran Pengetahuan Pedagang Mie basah trhadap Perilaku Penambahan Boraks dan Formalin Pada Mie Basah di Kantin Kantin Universita X Depok Tahun 2012," 2012.

[16] ATSDR, toxGuide for Boron B. 2011.

[17] N. Adinugroho, "Pengaruh Pemberian Boraks Dosis Bertingkat Terhadap Perubahan Gambaran Makroskopis Dan Mikroskopis Hepar Selama 28 Hari (Studi pada tikus wistar)," J. MEDIA Med. MUDA, pp. $1-12,2013$.

[18] R. L. Tatukude et al., "Gambaran histopatologi hati tikus wistar yang diberikan boraks 1," vol. 2, no. November, 2014.

[19] R. E. Chapin and W. W. Ku, "The Reproductive Toxicity of Boric Acid," pp. 87-91, 2000.

[20] Health Ministry Regulations No.1096 about hygiene sanitation catering services, Health Ministry Regulations No.1096. 2011.

[21] I. Trisnaini, "Bola-Bola Daging di Instalasi Gizi Rumah Sakit Hazard Analysis and Critical Control Point Meat Balls Making Process in," Kesmas, Natl. public Heal. J., vol. 7, pp. 131-138, 2012.

[22] R. Ningsih, "Penyuluhan Hygiene Sanitasi Makanan Dan Minuman, Serta Kualitas Makanan Yang Dijajakan Pedagang Di Lingkungan SDN Kota Samarinda," J. Kesehat. Masyarakat, KEMAS, vol. 10, no. 1, pp. 6472, 2014

[23] ratu ayu dewi Sartika, "Pengaruh Suhu Dan Lama Proses Menggoreng ( Deep Frying ) Terhadap Pembentukan Asam Lemak Trans," MAKARA SAINS, vol. 13, no. 1, pp. 23-28, 2009.

[24] E. A. Abriana, "Analysis of Trans Fatty Acid Content and Viscosity of the Repeteadly Used Frying Oil," Int. J. Agric. Syst. - Pasca UNHAS, vol. 1, no. 1, pp. 71$79,2013$.

[25] Y. Chen et al., "The analysis of trans fatty acid pro fi les in deep frying palm oil and chicken fi llets with an improved gas chromatography method," Food Control, vol. 44, pp. 191-197, 2014

[26] B. U. Sözen and C. Hecer, "Is HACCP a Difficult Food Safety System to Implement? HACCP Uygulanabilirliği Zor Olan Bir Sistem Midir?," vol. 7, no. 19, pp. 33-38, 2013. 